\title{
PEMANFAATAN SUMBERDAYA AIRTANAH UNTUK KEGIATAN PERTANIAN LAHAN KERING DI WILAYAH PESISIR KABUPATEN KULONPROGO
}

\author{
Sudarmadji $^{1}$ dan Ahmad Cahyadi ${ }^{2}$
}

${ }^{\text {I} D e p a r t e m e n ~ G e o g r a f i ~ L i n g k u n g a n, ~ F a k u l t a s ~ G e o g r a f i, ~ U n i v e r s i t a s ~ G a d j a h ~ M a d a, ~ s u d a r m a d j i @ g e o . u g m . a c . i d ~}$

${ }^{2}$ Departemen Geografi Lingkungan, Fakultas Geografi, Universitas Gadjah Mada, ahmadcahyadi@geo.ugm.ac.id

\begin{abstract}
ABSTRAK
Wilayah pesisir Kabupaten Kulon Progo terdiri dari bentuklahan beting gisik yang memiliki karakteristik geohidrologi yang unik. Potensi sumberdaya airtanah di lokasi tersebut cukup melimpah namun memiliki kondisi permukaan yang cenderung kering karena material pasir yang kasar menyebabkan air hujan dan air permukaan mudah meresap ke dalam sistem airtanah. Penelitian ini bertujuan untuk menganalisis kuantitas pemanfaatan airtanah untuk kegiatan pertanian di wilayah pesisir Kabupaten Kulon Progo. Pengumpulan data dilakukan dengan menganalisis data luasan lahan kering di Kabupaten Kulon Progo dan melakukan wawancara mendalam terkait dengan pemanfaatan sumberdaya airtanah dengan pengelola lahan. Hasil analisis menunjukkan bahwa pemanfaatan airtanah terutama digunakan saat musim kemarau, sedangkan ketika musim penghujan jumlah kebutuhan menurun drastis tergantikan oleh air hujan. Kebutuhan air untuk pertanian lahan kering rata-rata adalah 102 liter/hari/hektar dan kebutuhan pertahunnya sejumlah 135.128,07 $\mathrm{m}^{3} \mathrm{Jumlah}$ ini termasuk sangat besar mengingat kelulusan material pasir penyusunnya yang sangat tinggi dan penguapan yang tinggi pula.
\end{abstract}

Kata Kunci: Airtanah, Pesisir, Beting Gisik, Lahan Kering, Kulon Progo

\section{Pendahuluan}

Wilayah pesisir merupakan wilayah dengan sumberdaya yang tinggi. Hal ini menyebabkan kebanyakan wilayah pesisir memiliki pemanfaatan yang beraneka ragam. Konflik kepentingan sering kali muncul, untuk mendapatkan dukungan sumberdaya dan lokasi yang strategis. Oleh karenanya, tidak mengherankan banyak kota besar di seluruh dunia yang berkembang di wilayah pesisir.

Wilayah yang datar dan posisinya sebagai hulu dari banyak sungai menyebabkan wilayah pesisir memiliki potensi airtanah yang relatif besar [1,2]. Namun demikian, di sisi yang lain wilayah ini juga memiliki kerawanan terhadap intrusi air laut $[3,4]$. Hal ini mestinya menjadi pertimbangan yang serius dalam memanfaatkan sumberdaya airtanah di wilayah pesisir [5,6].

Wilayah pesisir Kabupaten Kulon Progo memiliki karakteristik unik. Bentuklahan yang berkembang di wilayah ini sangat terkait dengan keberadaannya yang menghadap Samudra Hindia, sehingga terbentuk bentuklahan asal marin. Selain itu, pembentukkan bentuklahan di lokasi ini sangat terkait dengan suplai material yang besar dari sungai dengan sedimen dominan adalah hasil erupsi gunungapi, sehingga material penyusun bentuklahan di lokasi ini didominasi sedimen gunungapi yang tidak padu dengan ukuran dominan pasir.

Lokasi wilayah pesisir Kulon Progo yang relatif jauh dari perkotaan menyebabkan wilayah ini lebih banyak digunakan untuk aktivitas pertanian lahan kering (Gambar 1). Luas lahan kering di Kabupaten Kulon Progo adalah seluas 16.674 hektar. Luas tersebut meliputi sawah tadah hujan sebesar 1.022 hektar dan tegalan seluas 15.652 hektar. Namun demikian, luas lahan kering yang terletak di wilayah pesisir hanya 5.115 hektar. Lahan kering di wilayah pesisir terdapat di empat Kecamanan, yaitu Kecamatan Wates, Kecamatan Galur, Kecamatan Temon dan Kecamatan Panjatan. 


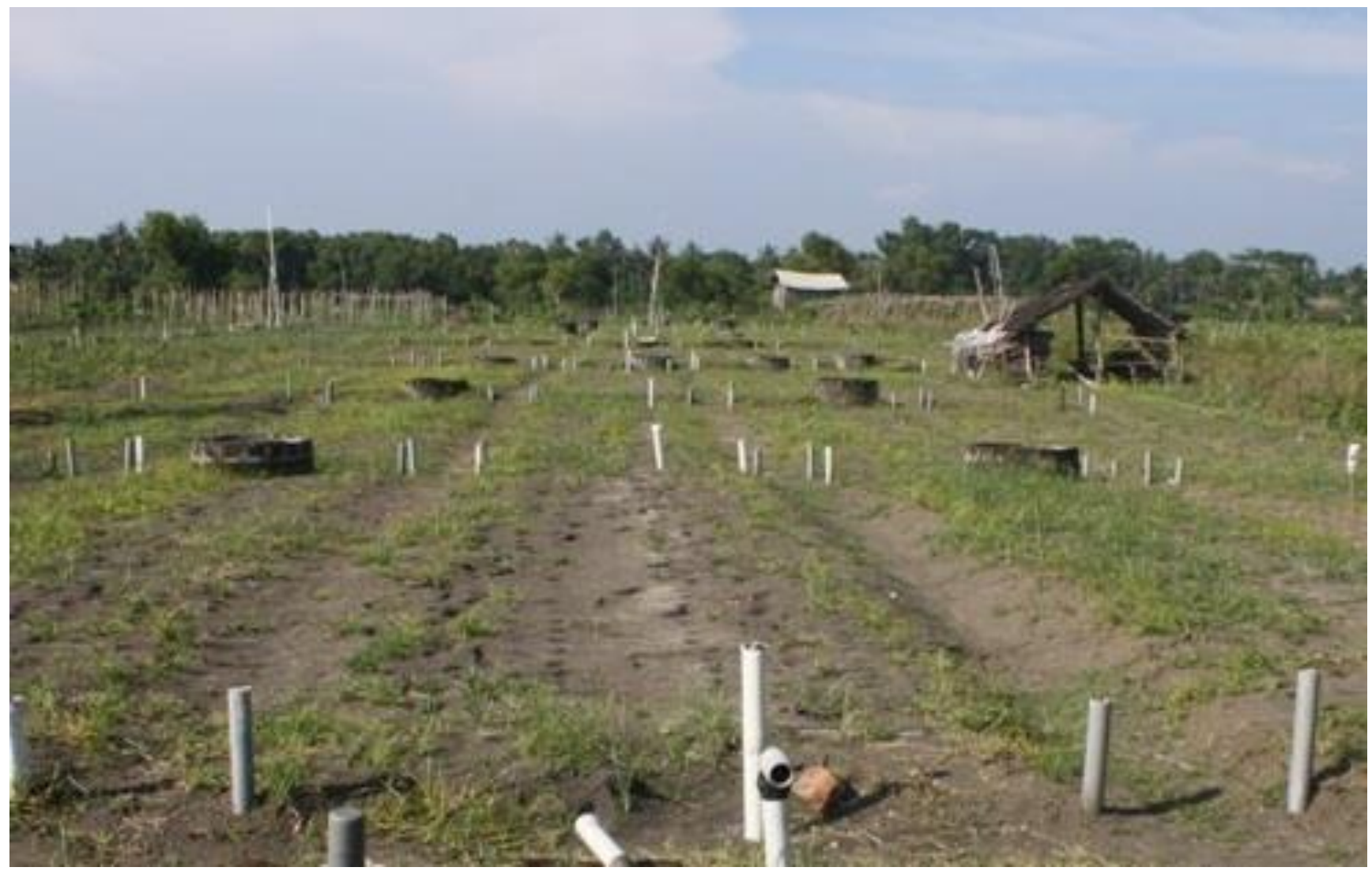

Gambar 1. Lahan Kering di Wilayah Pesisir Kabupaten Kulon Progo

Lahan kering di wilayah pesisir Kabupaten Kulon Progo menempati bentuklahan beting gisik. Hal ini menyebabkan wilayah ini tidak dapat dialiri oleh irigasi karena memiliki elevasi yang lebih tinggi dibandingkan dengan wilayah utaranya yang berupa dataran banjir dan rawa belakang. Selain itu, material pasir dengan permeabilitas yang tinggi menyebabkan tidak adanya aliran permukaan. Kedua kondisi tersebut menyebabkan airtanah menjadi sumber utama untuk mengairi lahan selain air hujan. Penelitian ini secara khusus bertujuan untuk menghitung kebutuhan airtanah yang digunakan untuk kegiatan pertanian lahan kering di wilayah pesisir Kabupaten Kulon Progo.

\section{Metode Penelitian}

Data yang dibutuhkan untuk analisis kebutuhan airtanah untuk kebutuhan pertanian lahan kering adalah data luas lahan kering dan data kebutuhan airtanah untuk luas tertentu per satuan waktu. Data luas lahan kering diperoleh dari data Badan Pusat Stastistik melalui terbitan Kabupaten
Kulon Progo dalam Angka Tahun 2015. Data kebutuhan airtanah diperoleh dari wawancara dengan petani lahan kering di wilayah pesisir Kabupaten Kulon Progo. Jumlah sampel responden adlah sejumlah 40 orang yang tersebar di empat kecamatan, yakni Kecamatan Wates, Kecamatan Galur, Kecamatan Temon dan Kecamatan Panjatan. Nilai kebutuhan airtanah adalah nilai rata-rata dari kebutuhan airtanah hasil analisis hasil wawancara.

\section{Hasil dan Pembahasan}

\subsection{Luas Wilayah Lahan Kering di Wilayah Pesisir} Kabupaten Kulon Progo

Luas lahan kering berdasarkan pada data Badan Pusat Statistik Kabupaten Kulon Progo yang terbit dalam buku Kabupaten Kulon Progo dalam Angka Tahun 2015 menunjukkan bahwa luas total lahan kering adalah seluas 16.674 hektar. Perhitungan luas lahan kering ini didasarkan pada luas lahan yang berupa sawah tadah hujan dan ladang. Namun demikian, luas lahan kering di wilayah pesisir di Kabupaten Kulon Progo hanya seluas 5.115 hektar. Tabel 1. 
menunjukkan luas lahan kering di empat kecamatan di kering di wilayah pesisir Kabupaten Kulon Progo berupa wilayah pesisir Kabupaten Kulon Progo. Keseluruhan lahan ladang.

Tabel 1. Luas Lahan Kering di Wilayah Pesisir Kabupaten Kulon Progo

\begin{tabular}{|c|l|r|r|}
\hline No. & \multicolumn{1}{|c|}{ Kecamatan } & Luas Lahan Kering (ha) & Luas Lahan Kering di Wilayah Pesisir (ha) \\
\hline 1. & Wates & 965 & 965 \\
\hline 2. & Temon & 1.298 & 1.211 \\
\hline 3. & Panjatan & 2.088 & 2.077 \\
\hline 4. & Galur & 868 & 862 \\
\hline \multicolumn{2}{|c|}{ Jumlah } & 5.219 & 5.115 \\
\hline
\end{tabular}

Sumber: Kabupaten Kulon Progo dalam Angka Tahun 2015

3.2. Kebutuhan Airtanah untuk Kebutuhan Pertanian Lahan Kering di Wilayah Pesisir Kabupaten Kulon Progo

Analisis kebutuhan airtanah di wilayah pesisir Kabupaten Kulon Progo didasarkan pada nilai rata-rata kebutuhan airtanah untuk lahan pertanian lahan kering untuk setiap satu hektar lahan kering. Hasil analisis menunjukkan bahwa kebutuhan airtanah untuk pertanian lahan kering paling sedikit adalah 63 liter/hektar/hari, sedangkan nilai paling besar adalah sejumlah 210 liter/hektar/hari. Nilai rata-rata penggunaan airtanah untuk lahan pertanian di wilayah pesisir Kabupaten Kulon Progo adalah 102 liter/hektar/hari. Kebutuhan airt yang besar di lokasi kajian disebabkan karena tekstur tanah yang berupa pasiran. Efisiensi pengaliran air melalui media pasir hanya sebesar $45 \%$, sedangkan kebutuhan air untuk infiltrasi dapat mencapai 35\% [7]. Di sisi yang lain, suhu yang tinggi di lokasi kajian menyebabkan tingginya evapotranspirasi tanaman, sehingga kebutuhan air akan semakin tinggi [8].

Tingginya kebutuhan air untuk pertanian selain disebabkan oleh faktor fisik lingkungan juga dipengaruhi oleh metode pengairan [6, 9]. Metode pengairan dengan irigasi saluran terbuka akan menyebabkan kebutuhan air menjadi sangat tinggi. Oleh karena itu, maka dibutuhkan modifikasi dalam pemenuhan kebutuhan air untuk tanaman, misalnya dengan irigasi tetes dan menghindari penggunaan saluran terbuka dan tanpa alas (langsung pada saluran sederhana dengan dasar tanah) [10].

Penyiraman tanaman pertanian di lokasi kajian hanya dilakukan pada saat tidak terjadi hujan pada suatu hari (Gambar 2). Penyiraman rata-rata hanya dilakukan sebanyak satu kali dalam satu hari. Oleh karena itu, maka perhitungan kebutuhan airtanah untuk kegiatan pertanian di wilayah pesisir Kabupaten Kulon Progo dirumuskan seperti pada persamaan 1 .

Kat $=($ A $\times$ K x HTH $) / 1.000$ (1)

\section{Keterangan:}

Kat $=$ Kebutuhan Airtanah $\left(\mathrm{m}^{3} /\right.$ tahun$) ; A=$ Luas Lahan Kering (ha); $\mathrm{K}=$ kebutuhan airtanah (liter/ha), HTH = jumlah hari hujan selama setahun

Jumlah hari tidak hujan di Kabupaten Kulon Progo ditentukan berdasarkan data hujan hasil pencatatan beberapa stasiun di lokasi kajian. Jumlah rata-rata hari hujan selama setahun di Kabupaten Kulon Progo adalah 106 hari. Hal ini berarti bahwa jumlah hari tidak hujan selama setahun adalah sejumlah 259 hari.

Tabel 2 menunjukkan kebutuhan airtanah untuk kepentingan pertanian di wilayah pesisir Kabupaten Kulon Progo pada masing-masing kecamatan. Jumlah kebutuhan airtanah total untuk kepentingan pertanian lahan kering di wilayah pesisir Kabupaten Kulon Progo adalah sejumlah 135.125,07 $\mathrm{m}^{3} /$ tahun. Kebutuhan airtanah terbanyak terdapat di Kecamatan Panjatan dan paling sedikit adalah Kecamatan Galur. 


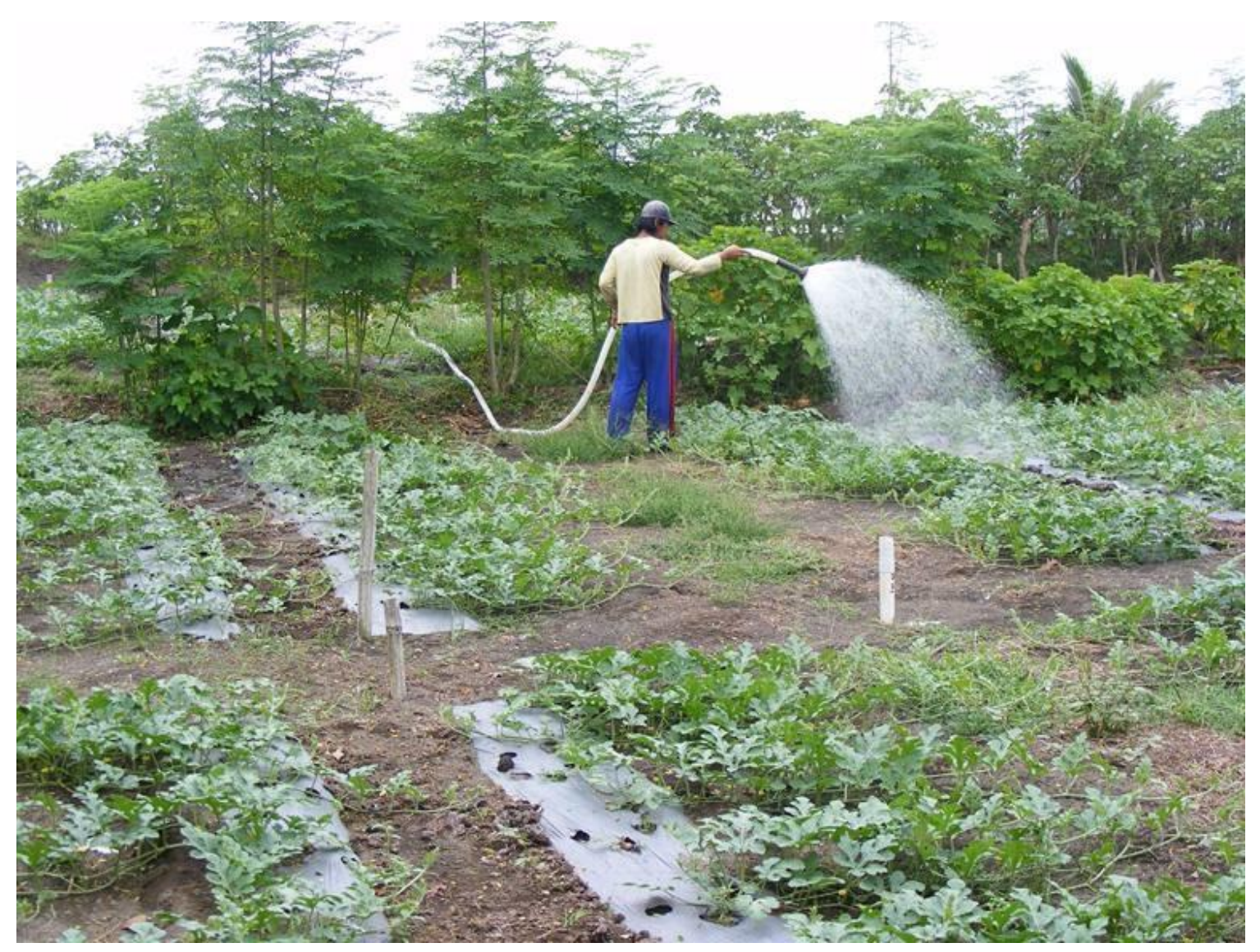

Gambar 2. Penyiraman Tanaman Pertanian pada Lahan Kering di Wilayah Pesisir Kabupaten Kulon Progo

Tabel 2. Kebutuhan Airtanah untuk Kegiatan Pertanian di Kabupaten Kulon Progo

\begin{tabular}{|c|l|r|r|}
\hline No & Kecamatan & Luas Lahan Kering (hektar) & Kebutuhan Airtanah untuk Pertanian $\left(\mathbf{m}^{\mathbf{3}}\right)$ \\
\hline 1 & Wates & 965 & $25.493,37$ \\
\hline 2 & Temon & 1.211 & $31.992,20$ \\
\hline 3 & Panjatan & 2.077 & $54.870,19$ \\
\hline 4 & Galur & 862 & $22.772,32$ \\
\hline \multicolumn{3}{|c|}{ Jumlah Kebutuhan Airtanah } & $\mathbf{1 3 5 . 1 2 8 , 0 7}$ \\
\hline
\end{tabular}




\section{Kesimpulan}

Kebutuhan rata-rata untuk kegiatan pertanian lahan kering di wilayah pesisir Kabupaten Kulon Progo adalah 102 liter/hektar/hari. Kebutuhan yang besar disebabkan karena faktor fisik lingkungan berupa tekstur tanah yang berupa pasiran dan suhu yang tinggi serta pola pemenuhan kebutuhan air tanaman yang dilakukan dengan penyiraman. Luas lahan kering di wilayah pesisir Kabupaten Kulon Progo adalah sebesar 5.115 hektar, sehingga dengan jumlah hari tidak hujan rata-rata setiap tahunnya sejumlah 259 hari maka jumlah kebutuhan airtanah untuk kegiatan pertanian lahan kering di Kabupaten Kulon Progo adalah sejumlah $135.128,07 \mathrm{~m}^{3} /$ tahun.

\section{Pengakuan dan Ucapan Terimakasih}

Penelitian ini merupakan sebagian dari data yang diperoleh dari penelitian Hibah Penelitian Unggulan Perguruan Tinggi Tahun 2016 dengan Judul "Pengelolaan Sumberdaya Air Terpadu Berbasis Teknologi Tepat Guna dan Kearifan Lokal di Daerah Rawan Bencana Kekeringan" yang dibiayai oleh Direktorat Riset dan Pengabdian Masyarakat, Direktorat Jenderal Penguatan Riset dan Pengembangan Kementerian Riset, Teknologi dan Pendidikan Tinggi. Penulis mengucapkan terima kasih kepada semua pihak yang telah membantu terlaksananya penelitian ini.

\section{REFERENSI}

[1] Gilli, E.; Mengan, C. dan Mudry, J. 2012. Hydrogeology: Objectives, Methods, Application. Boca Raton: CRC Press.

[2] Hoiscock, K.M. 2005. Hydrogeology: Principles and Practice. Malden, USA: Blackwell Pubishing.

[3] Younger, P.L. 2007. Groundwater in the Environment: an Introduction. Malden, USA: Blackwell Pubishing.

[4] Hudak, P.F. 2000. Principles of Hydrogeology. Boca Raton: CRC Press.

[5] Nonner, J.C. 2003. Introduction to Hydrogeology. Tokyo A.A. Balkema.

[6] Triadmodjo, B. 2009. Hidrologi Terapan. Yogyakarta: Beta Offset.

[7] Kurnia, U. 2004. Prospek Pengairan Pertanian Tanaman Semusim Lahan Kering. Jurnal Litbang Pertanian, 23(4): $130-138$.

[8] Penman, H.L. 1956. Estimating Evaporation. Trans.Amer. Geophys. Union, 37:37-46.

[9] Sanim, B. 2011. Sumberdaya Air dan Kesejahteraan Publik: Suatu Tinjauan Teoritis dan kajian Praktis. Bogor: IPB Press.

[10] Vadari, T.; Haryono dan Sutrisno, N. 1998. Aplikasi Irigasi Tetes untuk Budi Daya Semangka pada Tanah Vertisol di Rumah Kaca. Prosiding Pertemuan Pembahasan dan Komunikasi hasil Penelitian Tanah dan Agroklimat. Pusat Penelitian Tanah dan Agroklimat. 